Review Article

www.ijrap.net

\title{
A REVIEW ON RESPIRATORY SYSTEM PHYSIOLOGY AS DESCRIBED IN AYURVEDA
}

Verma Vandana*

P. G. Department of Kriya Sharira, State Ayurvedic College and Hospital, Lucknow University, Lucknow, India

Received on: 19/06/14 Revised on: 14/07/14 Accepted on: 19/07/14

*Corresponding author

Dr. Vandana Verma, Lecturer, P. G. Department of Kriya Sharira, State Ayurvedic College and Hospital, Lucknow University, Lucknow, India

E-mail: vandana.verma04@gmail.com

DOI: $10.7897 / 2277-4343.054117$

\section{ABSTRACT}

The Shvasankriya (respiration) consists of two words; Nishvas (inspiration) the act of breathing air inside the body through nose and Ucchvas (expiration), the act of breathing air outside the body through nose. The prana vayu is inspired through pranvaha srotas during inspiration. The inhaled prana vayu carries out the function like prinana, jivana and stimulates jatharanala (stimulation of digestive fire, and oxidation process). Respiratory system physiology is not directly described in Brihattrayi (Charaka, Sushruta, Astanga Hridaya). The process of respiration, respiratory disorders has been described in various Ayurvedic texts but its vivid description is not available as a whole. Description of different parts of respiratory tract organs and functions are found in description of pratyana sharir, srotas, kosthanga, prana vata, udana vata, rakta dhatu, rasa dhatu and diseases of nasa, kantha, pranavaha srotas etc. In this article an attempt has been made to understand respiratory system functional anatomy and physiology as it is described in Ayurveda by various scholars in view of modern science.

Keywords: Nishvas, Uchvas, prana vata, pranavaha srotas, anilayan, kloma nadi, apastambha.

\section{INTRODUCTION}

In general, respiration (shvasana) is a physiological process by which the oxygenated air (suddha vayu) is inhaled (nishavas) and simultaneously the deoxygenated air (vishuddha vayu) is exhaled (ucchvas). The process of respiration and the ventilator mechanism described by Sharangadhara is closely related to the modern physiological description of respiratory system. The descriptions of respiratory problems are mentioned in abnormalities of Pranavaha srotas. So, in order to understand the complete respiratory system physiology one should get through the description regarding the function of prana vata, udana vata, sadhaka pitta, avalambaka kapha and phupphusa, pranavaha Srotas etc.

\section{Functional Anatomy of Respiratory System}

The Pranavaha srotas is related with the shvasaprasvasa kriya. The following organs related with the shvashan prakriya could be considered as part of respiratory tract which are described in various contexts in Ayurveda:

Respiratory tract could be considered as:

- First part (upper respiratory tract), urdhva jatrugata i.e. from nose to pharynx. Nasa, nasaputa, nasavansh, Mukhavivara, upajihvika, talu, kantha,

- Second part (lower respiratory tract) from pharynx to lungs. Klomanadi, apastambha, phupphusa

Organs-

- Mouth cavity (mukhavivara)

- Nose (nasika)

- Throat (kantha)

- Pharynx (grasanika)

- Larynx (swaryantra)

- Trachea (klomanadi)

- Bronchi (apasthambh)

- Lungs (phupphus)

\section{Nasika (nose)}

Acharya Sushruta has described Nasa under Pratyanga and said it to be one in number. Sushruta said in context of outward opening (i.e. bahirmukha srotas) that there are 2 openings in the Nasa which could be taken as Nasachidra (nostrils) ${ }^{1}$. According to Charka there are nine major orifices seven in head and two below. Here he described two orifices in Nasa which could be related to Nasachira (nostrils) ${ }^{2}$. The Nasaguha starts from nasaputa and related to epiglottis or upper respiratory passage ${ }^{3}$. Nasa srotas has been mentioned in Sushruta uttartantra and under description of Nasasosha ${ }^{4}$. The region from nose to throat is like English letter ' $\mathrm{S}$ '. Arundutta has described it as Phanakriti marga.

\section{Mukhavivara (mouth cavity)}

Sushruta has described it as Vaktra. Prana vayu moves in the mouth cavity ${ }^{1}$.

\section{Kantha (throat)}

Kantha word is used for throat, oropharynx $x^{1,2}$. In the process of respiration, Kantha plays an important role, which is the shvasana path (the part of the upper respiratory tract). The lower part is attached to Grasnika (epiglottis) or swaryantra (larynx). Acharya Sharangdhar, has described Kantha in the context of respiration. It is the passage through which asuddha vayu gets out of the body and the air which is designated as Vishnupaamrita or the amberpiyusha (Oxygen) gets inside the body and sustains Ayu (life) in a human being ${ }^{5}$.

\section{Klomanadi (trachea)}

Gananatha Sen said Klomanadi is swaspranali (trachea). Vayu enters through mukha and nasika passage through Klomanadi, Apastambha and finally in Phupphus ${ }^{1}$. 


\section{Apasthambha (bronchi)}

On both sides of chest there are two vata carrying nadis (bronchi) known as Apasthambha, due to injury on it, causes death by filling of air in chest (pneumothorax) or cough or dyspnoea ${ }^{1}$.

\section{Phupphusa (lungs)}

While describing the body cavities i.e. Kosta (trunk consisting chest and abdomen) Sushruta described Phupphusa as one of the eight Kostanga. Sushruta has described that Hridya originates from the essence of blood and kapha which supports the prana carrying vessels. On the left and inferior aspect of heart are pliha and phupphusa, while on the right side are yakrita and kloma ${ }^{1}$, while Arundutta has described the position of phupphusa, Kloma and Yakrita on right side of heart. ${ }^{6}$ Here Yakrita is liver and kloma is said in context of pancreas or/right lung/gallbladder by various scholars ${ }^{7}$. Phupphusa are in pairs but Sushruta has not described it to in plural form. Arundutta has mentioned the position of kloma and phupphusa on same side and said it like mamsagranthi, so both are different kostanga. Based on the function of water balance, Patwardhan K. has considered Kloma for right lung. Kloma is considered as moola of Udakvaha srotas, so Udaka vaha srotas could be used for respiratory system. Kloma is the moolasthan of Udakavaha srotas means it is related with the transportation of water. In the commentary on Trishna nidana chapter of Astanga hridaya Todarmalla has described Kloma as KlomahPhupphusah. This means that Kloma and Phupphusa are synonyms. On the basis of this description Kloma could be considered for right lung since the role of lungs is the important in water balance and are route for insensible water loss (300-400 ml/ day). As air enters the respiratory tract, it is saturated with moisture, to a vapour pressure about $47 \mathrm{mmHg}$, before it is expelled. So, water is continuously lost through the lungs with respiration. ${ }^{8}$ So, far in this context left side phupphusa (left lung) and for right side Phupphusa (right lung) could be understood since Sushruta has mentioned the position of phupphusa on left side of heart and Arundutta has said on right side of heart. According to Sharangdhara in the left side of the body Phupphusa, Pliha and in the right side Yakrita is situated, intellect people stated Phupphusa as udanvayuadhar and function of Udana vayu is ucchavas. So it is clear that Phupphusa are related to respiration. Thus only Sharangadhar has directly described the relation of lungs with ventilation ${ }^{5}$.

\section{Anilayan}

Sushruta has used term Anilayana in description of swaraghana (a type of kantagata roga). Dalhana has further explained 'anilaayanesu vayubhageshu' which can be understood as svasamarga i.e. bronchial tree branching as well as alveoli ${ }^{4}$.

\section{Pranavaha srotas}

Acharaya Charak has described that moolastana of Pranavaha srotas are Hridaya (heart) and Mahasrotas (alimentary canal) ${ }^{2}$ where as Sushruta stated Hridaya (heart) and Rasavahi dhamani (blood vessels) as mool. Srotas is named according to its main content and the substance it carries (Prana, anna, udaka, ras) and not according to its functions or organs (respiration, digestion, musculo-skeletal system). Charak has considered Hridaya (heart) and Mahasrotas (alimentary canal) as mool because nutrients are obtained from anna (ahara) through alimentary canal and heart is responsible for circulation of annarasa and prana vayu (oxygen), both anna and prana vayu have been considered as prana. Most of the recent authors have correlated 'Respiratory system' with Pranavaha srotas on the basis of features of Pranavaha srotodusti with symptoms of respiratory system diseases. Pranavaha srorodusti produces various symptoms like atisrutam (increased rate of breathing), atibaddha (difficulty in breathing) kupitam, alpam or abhiksanam (breathing pattern is short with increased frequency), sa sahaba shula (breathing associated with sound and pain) etc, which shows similarity with various respiratory diseases like as Swasa, Kasa etc. In pathogenesis of shvasa, hikka pranavaha srotas get involved $^{2}$. But on careful observation one can find that these symptoms are related to rate and rhythm of respiration only which in turn are controlled by Nervous system. These respiratory symptoms might be because of disturbance in respiratory system organs, cardiovascular organs or nutritional deficiency due to alimentary system organs and involvement of nervous system. This might be the reason of considering hridaya (heart, brain) and Mahasrotas (alimentary canal) as mool of Pranavaha srotas. According to Chakrapani Pranavaha Srotas stands for that Srotas which transports a specific type of vata called Pranavata "Pranavahanamiti Pranasangyakavatavahanam, etaccha Pranakhyavishisatasya vayorvishisatasrotah ${ }^{9}$. All sensory and motor organs along with their pranavaha srotamsi are basically connected to the head (brain) in a fashion similar to connections between sunrays and the Sun. Sirasi indriyani indriya pranavahani ch, srotamsi suryamiva gabhastyah sansritani, Sarvahichesta vatena sa pranah praninam smritah ${ }^{2}$ in this verse Charak has mentioned that all the activities either physical or mental are due to Vata and that is why it is called as Prana of all living being. Prana vata is situated in the head and other active sites are chest and throat. It controls and regulates the intellectual functions, mental process and activities like spitting, sneezing, belching, respiration and deglutition. All these activities are governed by Nervous system so on the basis of above description pranavaha srotas stands for nervous system also ${ }^{8}$. So pranavaha srotas should not be studied only with the correlation of respiratory system but it must be studied in context to nervous system, cardiovascular and alimentary cannal (GIT).

\section{Respiration}

Ayurveda's description of "respiration" is very precise and somewhat poetic. It says that the pranavayu from the 'Nabhi' (navel) regions traverses through throat and passes out to consume the "nectar" in the air from atmosphere and comes back quickly to nourish the body to attain longevity. To understand the whole respiratory mechanism as described by Sharangadhar we must understand the function of the Prana vata, Udana vata, 
Sadhak pitta, Avalambak kapha, Rasa, Rakta, Mamsa, Asthi, Majja and Mala (subtle waste products).

\section{Function of Prana Vata}

Prana vayu situated in murdha (head, respiratory centres') gives stimulation to all the muscles of respiration, for expansion. It also stimulates diaphragm and abdominal muscles. Due to its activity the chest cavity broadens and inspiration occurs ${ }^{4}$. This function is described as "Pranah cha api avalambate". If respiration remains normal (with the proper functioning of Prana) life is maintained.

\section{Function of Udana Vata}

Udana vayu is responsible for the process of expiration ${ }^{3}$. Subtle, gaseous waste, formed during metabolism is expelled out in expiration. If waste is not thrown out, toxins remain in body and patient can become unconscious or may die. There should be proper coordination in inspiration and expiration.

\section{Function of Sadhaka Pitta}

Vitiated Sadhaka pitta can disturb the mental functions by producing mental stress, and fear which can affect respiratory rate.

\section{Function of Avalambaka Kapha}

Oily and slimy properties of Kapha protect the important organs like heart and lungs. Respiration is a continuous process, from birth to death. To prevent the damage of heart and lungs, from its continued activity, Kapha helps by its properties like cool, unction, soft and steady. Due to Kapha, heart and lungs can function for longer time, contraction and relaxation can occur smoothly ${ }^{1,4}$.

\section{Rakta, Mamsa, Meda, Asthi, Majja}

These body tissues are closely related with the respiration e.g. If rakta dhatu is deficient (anaemia), external prana (oxygen) cannot be efficiently transported and hence respiratory rate increases. Similarly in old age or in chronic stage of any disease, due to vitiation of Vata, respiratory rate increases. Normal respiration depends upon, normal anatomy and normal dosha, dhatu and mala functions. Normal physiology depends on normal anatomy. We cannot understand pathology unless we know anatomy, for example - If the patient comes with symptom of breathlessness we must find the cause, so that we can treat it properly. For this the physician must examine anatomy and physiology. Cause for breathlessness may be DNS (deviated nasal septum i.e. nasavansh) which is anatomical problem, or disturbance in Prana Udana action (physiology is disturbed) due to obstruction by Kapha ${ }^{10}$.

\section{Shvashan Prakriya (Respiration Process)}

Sharangadhara has explained this procedure in brief but in a very peculiar fashion. Prana-pavan (prana vayu), from umbilical region, after touching hritkamala goes out through Kantha. Then it reaches vishnupada and after drinking ambara-piyusha (oxygen), speedily comes back (punarayati vegatah). Then this prana vayu carries out the function like prinana, jivana and stimulates jatharanala or jatharagni (stimulation of digestive fire, means stimulation of oxidation process $)^{5}$. Ayurveda's description of "respiration" is very precise and somewhat poetic; this verse of Sharngadhara explains many important steps of respiratory system physiology systematically which are as follows:

\section{Ventilatory Mechanism}

The word nabhi (umbilical region), explains the participation of diaphragm and abdominal muscles in the process of ventilation. The direction of expiration from abdomen is in the upward direction, through chest and throat region.

\section{Gaseous exchange}

'Spristvahritakamalantaram' word indicates the gaseous exchange at the alveoli, after that the impure air comes outside through the kanta (throat, nasophrynx). Here word 'Hritakamalantar' could be synonymous for lungs as amberpiyush word is used for oxygen.

\section{Regulation of ventilation}

According to Ayurveda, Prana vata situated in murdha (brain) controls the process of inspiration by stimulating inspiratory group of neurons, by active dilatation of chest (expiration is a passive recoiling) and Udana vayu is responsible for expiration. Thus the activity of Prana and Udana vata refers to nervous regulation of ventilation.

\section{Transportation of gases}

In Pranavaha srotas mool, external prana dravya (anna, vayu) is converted into absorbable form and then it is transported with rakta throughout the body 'Prano hi raktam anudhavati' 2 . Sharngadhara also explains dhatuposhana or tissue nourishment through Vayu 'Pusnanti chanisham vayoha samyogatasarvadhtubhi'. Sira and dhamni (veins and arteries) arise from nabhi (heart) spread throughout the body and supply air to dhatus constantly ${ }^{5}$. Because of combination of vayu (air) and sharira (body) ayu (life) is existing 5 . Dhamanis (arteries) carry rasa dhatu all over the body and fill it with air ${ }^{5}$. All the above explanations suggest about the transportation of gases through circulation of blood and supply of oxygen to tissues. In Sadyovrana prakaran Srikantadutta has considered phupphusa as raktadhara ${ }^{11}$. This shows that phupphusa are highly vascular organ, as we know that it can accommodate blood two times of its normal capacity i.e. $900 \mathrm{ml}$ blood. ${ }^{12}$

Kshut (sneezing) is the sound produced in the nose by upward movement of prana and udana vayu and kapha in the head ${ }^{5}$. This description could be understood as sneezing reflex for clearance of upper respiratory tract.

\section{Respiratory rate (Shvasan Sankhya)}

Yogachudamani Upanishad has given the reference of exact number of normal respirations in human being.

According the above verse, calculations of respiration are as follows:

1 day $=21,000$ respirations

1 hour $=900$ respirations

1 minute $=15$ respirations 
The same respiratory rate $(15 / \mathrm{mm})$ is now, also accepted by the modern physiology. ${ }^{10}$

\section{Artificial Respiration (Pranapratyagaman)}

In Sharirsthan Charak has given various measures for resuscitation of just new born baby for establishment of respiration like striking of stones near the ears of child, sprinkling of hot and cold water on face, if does not gain vitality then the child should be fanned with a fan prepared with straps of bamboo ${ }^{2}$. All these measures indicate the description of artificial respiration.

\section{CONCLUSION}

On analysis of the whole scattered description related to respiratory system physiology it shows that respiratory system physiology is well described by Ayurvedic scholars and could be understood in view of modern physiology, which will be helpful in understanding the patho-physiology of diseases. In general, respiration (shvasana) is a physiological process by which the oxygenated air (shuddha vayu) is inhaled (nishavas) and simultaneously the deoxygenated air (vishuddha vayu) is exhaled (ucchvas). To understand the whole respiratory mechanism as described by Sharangadhar we must understand the function of the Prana vata, Udana vata, Sadhak pitta, Avalambak kapha, Rasa, Rakta , Mamsa, Asthi, Majja and Mala (subtle waste products). Pranavaha srotas should not be studied only with the correlation of respiratory system but it must be studied in context to other major systems (srotas) like nervous system (Regulation of respiration), cardiovascular system (Transportation of prana i.e. $\mathrm{O}_{2}$ ) and alimentary canal (as haemoglobin is main carrier of $\mathrm{O}_{2}$ and for synthesis of haemoglobin required nutrients are obtained through GIT).

\section{REFERENCES}

1. Murthy SRK. Sushruta Samhita Vol. I, English translation Publishers Chowkhambha orientalia, Varanasi, Reprint edition; 2008.

2. Sharma RK and Dash B. Charak samhita (with English translation and critical exposition based on Chakrapani dutt's Ayurveda dipika) vol I, II, III, IV Chowkhambha Sanskrita Series, Varanasi, sixth Edition; 2000.

3. Acharya JT. Sushruta Samhita of Sushruta with the Nibandhasangrah commentary Dalhanachary, Varanasi, India, Chowkhambha Surbharti prakashan, The Chowkhambha Ayurvijnan Granthmala No.42; 1994

4. Murthy SRK. Astanga Hrdayam English translation Vol. I, III Krishnadas Academy, Varanasi, third edition; 2000.

5. Murthy SRK. Sharangadhara Samhita English translation Chowkhambha orientalia, Varanasi, reprint edition; 2009.

6. Paradkar H. Astanga Hrdayam of Vagbhatt (with the commentaries Sarvangsundara of Arundutta and Ayurveda Rasayan of Hemadri), Chawkhambha Sanskrita Series, Varanasi; 1982.

7. Gauda SD. Prishadyam Sabdartha Shariram (Anatomical terminology of Ayurveda) Publisher Vaidyanath Ayurveda Bhavan private limited, Calcutta; 1964.

8. Patwardhan K. Human physiology in Ayurveda, Chowkhambha orientalia, Varanasi, India Jaikrishnadash Ayurveda Series No.134, first edition; 2005.

9. Kushvaha HS. Charak samhita, Shri Chakrapanidutta commentary in Hindi publishers Chowkhambha orientalia, Varanasi; 2005.

10. Ranade S, Deshpandey RR, Chobhe S. Text book of Sharir kriya Vijana, part-I, Chowkhambha Sanskrita Pratisthan, Varanasi, First edition; 2007.

11. Murthy SRK. Madhava Nidanam of Madhavakara English translation Chowkhambha Orientalia, Varanasi; 2009.

12. Guyton C. Text book of medical physiology, eighth edition; 1991.

\section{Cite this article as:}

Verma Vandana. A review on respiratory system physiology as described in Ayurveda. Int. J. Res. Ayurveda Pharm. 2014;5(4):578-581 http://dx.doi.org/10.7897/2277-4343.054117 